Egyptian Journal of Aquatic Biology \& Fisheries

Zoology Department, Faculty of Science,

Ain Shams University, Cairo, Egypt.

ISSN $1110-6131$

Vol. 23(2): 165 - 182 (2019)

www.ejabf.journals.ekb.eg

\title{
Monitoring of Oxidative Stress Biomarkers and Toxicity of Lead and Mercury in Catfish of Lake Mariout, Egypt: The Role of Meso -2, 3-Dimercaptosuccinic Acid (DMSA)
}

\section{Nema A. Mohamed ${ }^{1}$, Awatef M. Ali ${ }^{1}$, Shnoudy A. Bakhoum ${ }^{2}$, Heba H. Abdel-Kader ${ }^{2 *}$ and Mohamed A. Ahmed ${ }^{2}$}

1- Department of Zoology, Faculty of Science, Alexandria University, Egypt.

2- Fish Physiology Lab., National Institute of Oceanography and Fisheries, Egypt.

*Corresponding author: hebaelalkamy3232@ gmail.com

\section{ARTICLE INFO \\ Article History: \\ Online: April 2019 \\ Keywords: \\ Monitoring \\ oxidative stress \\ Lead \\ Mercury \\ toxicity \\ Catfish \\ Lake Mariout}

Received: Feb. 19, 2019

Accepted: march 30, 2019

\section{ABSTRACT}

The present investigation was designed to evaluate the dangerous effects of the $\mathrm{Pb}$ and $\mathrm{Hg}$ on Clarias gariepinus inhabiting Lake Mariout and assay the possible protective effect of meso-2, 3 dimercaptosuccinic acid (DMSA). The test fish were divided into four groups kept in plastic tanks (20 fish each) containing 30L of Lake Mariout water. Group (1): Standard group (zero time); Group (2): Unexposed DMSA group, Group (3): Low dose DMSA group; Group (4): High dose DMSA group. Fish exposed to DMSA showed significant decrease in lead $(P \leq 0.05)$ and mercury concentrations $(P \leq 0.05)$ in kidney, liver, gills, muscle and blood than unexposed group. The present results clearly indicate a significant decrease in RBCs, Hb, Hct, and platelet counts while a significant increase in $\mathrm{MCH}, \mathrm{MCHC}$, and WBCs in the Clarias gariepinus collected from the main basin of Lake Mariout. A marked significant decrease in AST, ALT, urea, creatinine $(P \leq 0.05)$ was observed in DMSA groups. A significant increase in CAT, GPX and SOD was observed after exposure to DMSA. In addition, DMSA exposure improved the histopathological alterations in fish liver and kidney.

\section{INTRODUCTION}

Egypt and the Middle East region are facing water pollution, which is one of the environmental and public health problems. Pollution is generally associated with industries waste that is one of the river Nile ecological problems (El-Sheikh et al., 2010).

Heavy metals are the most common pollutants in the coastal area (Krishna et al., 2013). Lead $(\mathrm{Pb})$ and mercury $(\mathrm{Hg})$ are toxic at even low concentrations (Pugazhvendan et al., 2012). Excessive exposure to lead may cause chronic nephropathy, hypertension, pathological changes and also reproductive impairments (Falayi and Amatosero, 2014). Mercury $\mathrm{Hg}$ is a wide spread metal pollutant of high toxicity to aquatic animals including fishes. Oxidative stress, inflammation, thrombosis and mitochondrial dysfunction are the most side effects of mercury (Begam and Sengupta, 2014).

Lake Mariout is the major source of pollution in the Mediterranean Sea through El-Max Bay in South Alexandria. The Lake Mariout receives polluted water from 
many sources, including industrial and domestic effluents. The total discharge of primary treated sewage is about $916,000 \mathrm{~m}^{3} /$ day (El-Bestawy et al., 2014).

African catfish (Clarias gariepinus) has a great commercial importance because it is considered as one of the healthiest and cheapest fish as a source of protein and sufficient omega fatty acids (Ebrahimi and Taherianfard, 2011). Generally, fish is not only used for human consumption, but also used as a good source of animal meal (Emam and Badia, 2014). Consumption of fish from Lake Mariout is considered a health problem. Amr et al. (2005) stated that the concentrations of heavy metals in fish samples from the Main Basin were higher than those in water samples. It can therefore be a good model to study responses to various environmental pollutants (Damian et al., 2014).

Metals are well known inducers of oxidative damage in fishes reflecting metal contamination of the aquatic ecosystem (Kumar and Nandan, 2014). Antioxidant is an agent that can neutralize the oxidant effect of free radicals, including some natural and other substances (Mahmoud et al., 2013). Meso-2, 3-dimercaptosuccinic acid (DMSA) is a dithiol compound, has two-SH groups (Flora et al., 2011). It was 40 years ago, DMSA was known as an effective antidote to heavy metal poisoning in human.

To avoid the aquatic pollution there is need to use new strategies and technologies for detoxifying the river water to improve the health of its fish, and, in turn, that of the humans who consume them. Thus, the objective of the present study was to evaluate the possible protective effects of DMSA against the lead and mercury toxicity on blood, liver and kidney and the oxidant status of Clarias gariepinus which accompanied by physiological and histopathological studies.

\section{MATERIALS AND METHODS}

\section{Chemical}

The antidote dimercaptosuccinic acid (DMSA, Succimer), a white powder with molecular weight 182.21. DMSA, was obtained from the Acros Organics Company, USA.

\section{Study area}

Lake Mariout is an intermediate stage of discharge of multiple land based sources to the El-Mex Bay. The fact that domestic sewage, industrial and agricultural water are discharged continuously into the lake.

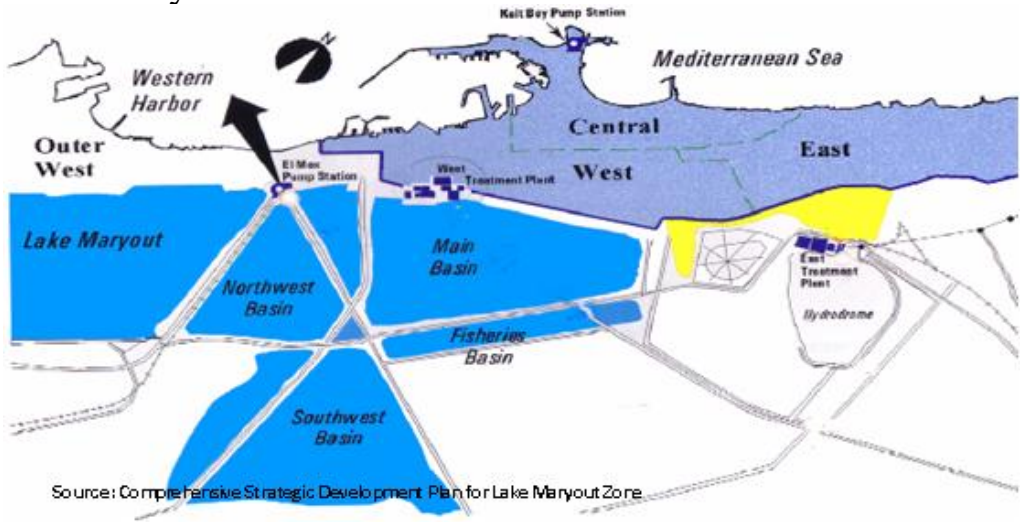

Fig. 1: The basins of Lake Mariout 


\section{Experimental fish}

Clarias gariepinus (Catfish) $(115 \pm 5.0 \mathrm{~g}, 20$ to $23 \mathrm{~cm})$ were caught from the main basin of Lake Mariout. In the laboratory, fish were placed in 30L aquaria (Twenty fish/aquarium) of Lake Mariout water, which was renewed weekly. Aquaria were maintained within an appropriate range of temperature $\left(22^{\circ} \mathrm{C}-25^{\circ} \mathrm{C}\right)$ and $\mathrm{pH}(8.0$ 8.8). Four recirculating aquarium systems the bio-filters and aeration were used. Fish were acclimated to the laboratory conditions for 15 days. For the entire duration of the experiment (60 days), the fish were fed with commercial fish feed, a rate of $3 \%$ body weight daily. All animal procedures and the experimental protocols were carried out according to the guidelines of the National Institutes of Health (NIH).

\section{Experimental design:}

In the laboratory, fish were divided into 4 groups (20 each) as follows:

Group I: Standard group (Zero time): fish of this group were sacrificed on the same day of collection.

Group II: Unexposed DMSA group: fish of this group stayed without treatment.

Group III: Low dose DMSA group: fish of this group treated with $5 \mathrm{mg} / \mathrm{kg} \mathrm{BW} / \mathrm{L}$ of DMSA.

Group VI: High dose DMSA group: fish of this group treated with $18 \mathrm{mg} / \mathrm{kg} \mathrm{BW/L} \mathrm{of}$ DMSA.

The experiment continued for 60 days. The low and high doses were selected according to Palaniappan and Vijayasundaram (2009).

\section{Water analysis}

Lead levels in water samples were estimated by using Air/Acetylene flame atomic absorption spectrophotometer (UNICAM 696 AA Spectrometer). Mercury levels in water samples were estimated by using Flameless atomic absorption spectrophotometer equipped with (MHS) mercury hybrid system "Cold Vapor Technique".

\section{Bioaccumulation analysis}

Lead and mercury concentrations in tissue were determined by using the methods of Al-Balawi et al. (2013) and Diaz-Ravina et al. (1994), respectively. Lead (Selander and Cramer, 1968) and mercury (Kanno et al., 1985) concentrations in blood were also determined.

\section{Determination of transfer factor (TF):}

Transfer factor is the ratio between the accumulated concentration of a given pollutant in any organ and its dissolved concentration in water. It is calculated by dividing the concentrations of a heavy metal in fish organ by the heavy metal found in water (Olabanji and Oluyemi, 2014).

$$
\text { Transfer ratio }(\mathrm{TF})=\frac{\text { Metal concentration in fish organ }}{\text { Metal concentration in water }}
$$

\section{Preparation of blood and serum}

The blood samples were collected by caudal vein into clean, dry, sterile container containing EDTA and free anti-coagulated container. The anti-coagulated blood sample was used for the determination of the hematological parameters. Free anti-coagulated blood samples were used for the serum preparation. They were centrifuged at $3000 \mathrm{rpm}$ for 15 minutes and the serum was collected in capped sterile tubes and used for biochemical measurements.

\section{Hematological studies}

Hematological parameters include erythrocyte count (RBC), hemoglobin concentration $(\mathrm{Hb})$, hematocrit value $(\mathrm{Hct})$ platelet counts and the blood indices 
(MCV, MCH, MCHC) were calculated. Furthermore, the total number of leukocytes and a differential white blood cell count were counted (Dacie and Lewis, 1975).

\section{Biochemical analysis}

The levels of aspartate aminotransferase (AST) (E.C.2.6.1.2.) and alanine aminotransferase (ALT) (Reitmena and Frankel., 1957) were determined. Urea and creatinine were estimated according to the methods of Henry (1974) and Tietz (1995), respectively. Catalase (CAT) (EC 1.11.1.6), superoxide dismutase (SOD) (EC 1.15.1.1) and glutathione peroxidase (GPX) (EC 1.11.1.9) were estimated in liver according to the methods of Abei (1984), Nishikimi et al. (1972) and Paglia and Valentine (1967), respectively.

\section{Light and electron microscope examination}

Tissue specimens of the liver and kidney were removed, fixed in $10 \%$ formalin solution and routinely processed for paraffin embedding. Sections were cut at $3 \mathrm{~mm}$ and stained with Haematoxylin and Eosin (H\&E) according to Bancroft and Gamble (2002). Liver and kidney samples were fixed by immersion in $2.5 \%$ glutaraldehyde in phosphate buffer solution $(\mathrm{pH} 7.2)$ at $4^{\circ} \mathrm{C}$. The samples were post-fixed in $2 \%$ osmium tetroxide for two hours at $4^{\circ} \mathrm{C}$. They were rinsed again in the buffer, dehydrated in a graded ethanol series, and embedded in Epon-Araldite mixture. Ultrathin sections were cut and stained with lead citrate and uranyl acetate according to Reynolds (1963). The specimens were viewed in Joel 100 CX TEM.

\section{Statistical analysis}

Data were tested using one-way ANOVA followed by Tukey honest-significant difference test (TSD) for the comparison between different treatments, when F-values were significant. All collected data in the present study were subjected to statistical analysis by using SPSS version 22 software.

\section{RESULTS}

\section{The effect of DMSA exposure on the water lead and mercury concentrations}

The heavy metal residues in Lake Mariout water exposed to DMSA showed a significant $(\mathrm{p} \leq 0.05)$ decrease in lead and mercury concentrations as compared to the unexposed group and standard group (Table 1). Tukey honest-significant difference test (TSD) revealed that the difference in the concentration of lead was significantly different in the two doses of DMSA. While mercury concentration was statistically insignificant $(\mathrm{p} \leq 0.05)$ between the low and high dose DMSA groups (Table 1$)$.

Table 1: Lead and mercury concentrations (mg/l) in water of Lake Maryout before and after DMSA exposure.

\begin{tabular}{|c|c|c|c|c|c|c|c|c|}
\hline & \multicolumn{2}{|c|}{$\begin{array}{l}\text { Standard group } \\
\text { (Zero time) }\end{array}$} & \multicolumn{2}{|c|}{$\begin{array}{l}\text { Unexposed } \\
\text { DMSA group } \\
\text { (60 days) }\end{array}$} & \multicolumn{2}{|c|}{$\begin{array}{l}\text { Low dose } \\
\text { DMSA group } \\
\text { (60 days) }\end{array}$} & \multicolumn{2}{|c|}{$\begin{array}{l}\text { High dose } \\
\text { DMSA group } \\
\text { (60 days) }\end{array}$} \\
\hline & Lead & Mercury & Lead & Mercury & Lead & Mercury & Lead & Mercury \\
\hline $\begin{array}{l}\text { Water } \\
(\mathrm{mg} / \mathrm{l})\end{array}$ & $\begin{array}{c}5.25 \\
\pm 0.92^{\mathrm{a}}\end{array}$ & $\begin{array}{c}1.60 \\
\pm 0.43^{\mathrm{a}}\end{array}$ & $\begin{array}{c}4.60 \\
\pm 0.14\end{array}$ & $\begin{aligned} & 1.90 \\
\pm & 0.28^{b}\end{aligned}$ & $\begin{array}{l}2.25 \pm \\
0.21^{\mathrm{c}}\end{array}$ & $\begin{array}{l}0.59 \pm \\
0.18^{c}\end{array}$ & $\begin{array}{l}1.75 \pm \\
0.07^{\text {cd }}\end{array}$ & $\begin{array}{l}0.53 \pm \\
0.09^{c}\end{array}$ \\
\hline
\end{tabular}

Values are expressed as mean $\pm \mathrm{SD}, \mathrm{n}=10$. Means in a row with no common superscripts $(\mathrm{a}, \mathrm{b}, \mathrm{c}, \mathrm{d})$ are significantly different $(\mathrm{p} \leq 0.05)$.

The effect of DMSA exposure on the tissue lead and mercury concentrations

Fish exposed to DMSA showed significant $(\mathrm{p} \leq 0.05)$ decrease in lead and mercury concentrations in kidney, liver, gills, muscle and blood in comparison with unexposed groups (Table 2). TSD revealed that the difference in the concentrations of tissue lead and mercury was statistically significant between the low and high dose DMSA groups (Table 2). 
Table 2: Lead and Mercury concentrations before and after DMSA exposure in different organs and blood of catfish.

\begin{tabular}{|c|c|c|c|c|c|c|c|c|}
\hline \multirow[t]{2}{*}{ Organs } & \multicolumn{2}{|c|}{$\begin{array}{l}\text { Standard group } \\
\text { (Zero time) }\end{array}$} & \multicolumn{2}{|c|}{$\begin{array}{l}\text { Unexposed } \\
\text { DMSA group } \\
\text { (60 days) }\end{array}$} & \multicolumn{2}{|c|}{$\begin{array}{l}\text { Low dose } \\
\text { DMSA group } \\
\text { (60 days) }\end{array}$} & \multicolumn{2}{|c|}{$\begin{array}{l}\text { High dose } \\
\text { DMSA group } \\
\text { (60 days) }\end{array}$} \\
\hline & $\begin{array}{l}\text { Lead } \\
(\mu \mathrm{g} / \mathrm{g})\end{array}$ & $\begin{array}{l}\text { Mercury } \\
(\mu g / g)\end{array}$ & $\begin{array}{l}\text { Lead } \\
(\mu \mathrm{g} / \mathrm{g})\end{array}$ & $\begin{array}{l}\text { Mercury } \\
(\mu \mathrm{g} / \mathrm{g})\end{array}$ & $\begin{array}{l}\text { Lead } \\
(\mu \mathrm{g} / \mathrm{g})\end{array}$ & $\begin{array}{l}\text { Mercury } \\
(\mu \mathrm{g} / \mathrm{g})\end{array}$ & $\begin{array}{l}\text { Lead } \\
(\mu \mathrm{g} / \mathrm{g})\end{array}$ & $\begin{array}{l}\text { Mercury } \\
(\mu \mathrm{g} / \mathrm{g})\end{array}$ \\
\hline \multirow[t]{2}{*}{ Kidney } & 3.51 & 1.1 & 3.88 & 2.02 & 1.89 & 0.69 & 1.16 & 0.49 \\
\hline & $\pm 1.12^{\mathrm{a}}$ & $\pm 0.20^{\mathrm{a}}$ & $\pm 0.84^{b}$ & $\pm 0.26^{b}$ & $\pm 0.55^{c}$ & $\pm 0.17^{c}$ & $\pm 0.72^{\mathrm{cd}}$ & $\pm 0.16^{c d}$ \\
\hline \multirow[t]{2}{*}{ Liver } & 2.18 & 1.04 & 4.14 & 1.68 & 1.45 & 0.59 & 0.83 & 0.31 \\
\hline & $\pm 0.51^{\mathrm{a}}$ & $\pm 0.31^{\mathrm{a}}$ & $\pm 0.51^{b}$ & $\pm 0.20^{b}$ & $\pm 0.51^{c}$ & $\pm 0.14^{c}$ & $\pm 0.17^{\text {cd }}$ & $\pm 0.11^{c d}$ \\
\hline \multirow[t]{2}{*}{ Gills } & 2.69 & 2.01 & 3.70 & 2.32 & 1.33 & 0.46 & 1.02 & 0.38 \\
\hline & $\pm 0.60^{a}$ & $\pm 0.42^{\mathrm{a}}$ & $\pm 0.53^{b}$ & $\pm 0.56^{b}$ & $\pm 0.40^{c}$ & $\pm 0.18^{c}$ & $\pm 0.25^{\mathrm{cd}}$ & $\pm 0.14^{\mathrm{cd}}$ \\
\hline \multirow[t]{2}{*}{ Muscle } & 1.82 & 0.64 & 2.58 & 2.25 & 1.20 & 0.54 & 0.85 & 0.39 \\
\hline & $\pm 0.62^{a}$ & $\pm 0.33^{a}$ & $\pm 0.52^{b}$ & $\pm 0.77^{b}$ & $\pm 0.60^{c}$ & $\pm 0.25^{c}$ & $\pm 0.18^{\mathrm{cd}}$ & $\pm 0.14^{\mathrm{cd}}$ \\
\hline \multirow[t]{2}{*}{ Blood } & 2.40 & 0.60 & 3.28 & 0.73 & 1.90 & 0.56 & 1.25 & 0.43 \\
\hline & $\pm 1.41^{\mathrm{a}}$ & $\pm 0.21^{\mathrm{a}}$ & $\pm 0.71^{b}$ & $\pm 0.25^{b}$ & $\pm 0.67^{c}$ & $\pm 0.18^{c}$ & $\pm 0.38^{\mathrm{cd}}$ & $\pm 0.25^{\mathrm{cd}}$ \\
\hline
\end{tabular}

Values are expressed as mean $\pm \mathrm{SD}, \mathrm{n}=10$. Means in a row with no common superscripts $(\mathrm{a}, \mathrm{b}, \mathrm{c}, \mathrm{d})$ are significantly different $(\mathrm{p} \leq 0.05)$.

\section{The effect of DMSA exposure on transfer factor}

Fish exposed to DMSA showed decreases in the transfer factor (TF) of lead and mercury in kidney, liver, gills, muscles and blood as compared to unexposed DMSA groups (Table 3). The transfer factor of lead and mercury in different organs showed significant decrease in high dose exposed DMSA group as compared to the low dose DMSA group.

Table 3: Transfer factor of lead and mercury before and after DMSA exposure in different organs and blood of catfish.

\begin{tabular}{|c|c|c|c|c|c|c|c|c|}
\hline \multirow[t]{2}{*}{ Organs } & \multicolumn{2}{|c|}{$\begin{array}{l}\text { Standard group } \\
\text { (Zero time) }\end{array}$} & \multicolumn{2}{|c|}{$\begin{array}{l}\text { Unexposed } \\
\text { DMSA group } \\
\text { (60 days) }\end{array}$} & \multicolumn{2}{|c|}{$\begin{array}{c}\text { Low dose } \\
\text { DMSA group } \\
\text { (60 days) } \\
\end{array}$} & \multicolumn{2}{|c|}{$\begin{array}{c}\text { High dose } \\
\text { DMSA group } \\
\text { (60 days) }\end{array}$} \\
\hline & Lead & Mercury & Lead & Mercury & Lead & Mercury & Lead & Mercury \\
\hline \multirow[t]{2}{*}{ Kidney } & 0.67 & 0.68 & 0.84 & 1.03 & 0.41 & 0.36 & 0.38 & 0.26 \\
\hline & $\begin{array}{c} \pm \\
0.061^{\mathrm{a}}\end{array}$ & $\stackrel{ \pm}{ \pm}$ & 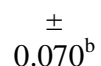 & $\begin{array}{c} \pm \\
0.089^{\mathrm{b}}\end{array}$ & $\begin{array}{c} \pm \\
0.060^{\mathrm{c}}\end{array}$ & $\begin{array}{c} \pm \\
0.093^{\mathrm{c}}\end{array}$ & $\stackrel{ \pm^{\mathrm{cd}}}{0.101^{1}}$ & $\stackrel{ \pm}{ \pm} 0^{\mathrm{cd}}$ \\
\hline \multirow[t]{3}{*}{ Liver } & 0.45 & 0.71 & 0.90 & 0.57 & 0.32 & 0.31 & 0.18 & 0.16 \\
\hline & \pm & \pm & \pm & \pm & \pm & \pm & \pm & \pm \\
\hline & $0.038^{\mathrm{a}}$ & $0.080^{\mathrm{a}}$ & $0.075^{\mathrm{b}}$ & $0.044^{\mathrm{b}}$ & $0.046^{\mathrm{c}}$ & $0.080^{\mathrm{c}}$ & $0.047^{\mathrm{cd}}$ & $0.053^{\mathrm{cd}}$ \\
\hline \multirow[t]{3}{*}{ Gills } & 0.51 & 1.30 & 0.80 & 1.12 & 0.29 & 0.24 & 0.40 & 0.20 \\
\hline & \pm & \pm & \pm & \pm & \pm & \pm & \pm & \pm \\
\hline & $0.047^{\mathrm{a}}$ & $0.117^{\mathrm{a}}$ & $0.067^{\mathrm{b}}$ & $0.102^{\mathrm{b}}$ & $0.042^{\mathrm{c}}$ & $0.062^{c}$ & $0.104^{\mathrm{cd}}$ & $0.064^{\mathrm{cd}}$ \\
\hline \multirow[t]{2}{*}{ Muscle } & 0.41 & 0.68 & 0.56 & 1.18 & 0.26 & 0.28 & 0.19 & 0.21 \\
\hline & $\stackrel{ \pm}{ \pm}$ & $\begin{array}{c} \pm \\
0.036^{\mathrm{a}}\end{array}$ & $\stackrel{ \pm}{ \pm}$ & $\begin{array}{c} \pm \\
0.099^{\mathrm{b}}\end{array}$ & $\stackrel{ \pm}{ \pm}$ & $\stackrel{ \pm}{ \pm}$ & $\frac{ \pm}{ \pm}$ & $0.066^{\mathrm{cd}}$ \\
\hline \multirow[t]{2}{*}{ Blood } & 0.49 & 0.36 & 0.71 & 0.90 & 0.38 & 0.35 & 0.31 & 0.32 \\
\hline & $\begin{array}{c} \pm \\
0.042^{\mathrm{a}}\end{array}$ & $\stackrel{ \pm}{ \pm}$ & $\begin{array}{c} \pm \\
0.059^{\mathrm{b}}\end{array}$ & 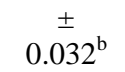 & $\begin{array}{c} \pm \\
0.060^{\mathrm{c}}\end{array}$ & $\stackrel{ \pm}{ \pm}$ & $\stackrel{ \pm}{ \pm .100^{\mathrm{cd}}}$ & $\stackrel{ \pm}{ \pm}{ }^{\mathrm{cd}}$ \\
\hline
\end{tabular}

Values are expressed as mean $\pm \mathrm{SD}, \mathrm{n}=10$. Means in a row with no common superscripts $(\mathrm{a}, \mathrm{b}, \mathrm{c}, \mathrm{d})$ are significantly different $(\mathrm{p} \leq 0.05)$.

The effect of DMSA exposure on hematological parameter

RBCs, $\mathrm{Hb}$, Hct and platelet count were significantly $(P \leq 0.05)$ increased in DMSA exposed groups as compared to unexposed and standard groups (Table 4). MCV, $\mathrm{MCH}$ and MCHC were significantly decreased in DMSA groups as compared with unexposed. A marked significant $(P \leq 0.05)$ decrease in WBCs in DMSA groups comparing with unexposed and standard groups was observed (Table 5). An increase 
in lymphocyte and a decrease in monocyte and neutrophil counts were observed in DMSA exposed groups in comparison with unexposed and standard groups.

Table 4: Hematological changes in catfish before and after DMSA exposure:

\begin{tabular}{|c|c|c|c|c|}
\hline Parameter & $\begin{array}{l}\text { Standard group } \\
\text { (Zero time) }\end{array}$ & $\begin{array}{l}\text { Unexposed DMSA } \\
\text { group (60 days) }\end{array}$ & $\begin{array}{c}\text { Low dose DMSA } \\
\text { group (60 days) }\end{array}$ & $\begin{array}{l}\text { High dose DMSA } \\
\text { group ( } 60 \text { days) }\end{array}$ \\
\hline \multirow[t]{3}{*}{$\mathrm{RBCs}\left(\times 10^{6} / \mathrm{mm}^{3}\right)$} & 3.39 & 3.00 & 4.15 & 4.30 \\
\hline & \pm & \pm & \pm & \pm \\
\hline & $0.30^{\mathrm{a}}$ & $0.60^{\mathrm{a}}$ & $0.40^{\mathrm{c}}$ & $0.52^{\mathrm{cd}}$ \\
\hline \multirow[t]{3}{*}{$\mathrm{Hb}(\mathrm{g} / \mathrm{dl})$} & 9.50 & 7.22 & 11.18 & 12.18 \\
\hline & \pm & \pm & \pm & \pm \\
\hline & $0.81^{\mathrm{a}}$ & $1 . \overline{6} 1^{\mathrm{b}}$ & $1.29^{\mathrm{c}}$ & $1.29^{\mathrm{cd}}$ \\
\hline \multirow[t]{3}{*}{$\operatorname{Hct}(\%)$} & 27.88 & 25.00 & 34.40 & 39.40 \\
\hline & \pm & \pm & \pm & \pm \\
\hline & $4.92^{\mathrm{a}}$ & $5.24^{\mathrm{a}}$ & $5.60^{c}$ & $7.60^{\mathrm{cd}}$ \\
\hline \multirow[t]{3}{*}{$\operatorname{MCV}(f l)$} & 90.36 & 92.70 & 82.60 & 81.11 \\
\hline & \pm & \pm & \pm & \pm \\
\hline & $11.59^{\mathrm{a}}$ & $22.63^{\mathrm{a}}$ & $7.05^{\mathrm{c}}$ & $08.75^{\mathrm{d}}$ \\
\hline \multirow[t]{3}{*}{$\mathrm{MCH}(\mathrm{pg})$} & 34.28 & 34.47 & 25.96 & 24.38 \\
\hline & \pm & \pm & \pm & \pm \\
\hline & $2.30^{\mathrm{a}}$ & $8.65^{\mathrm{a}}$ & $2.05^{\mathrm{c}}$ & $1.64^{\mathrm{d}}$ \\
\hline \multirow[t]{3}{*}{$\mathrm{MCHC}(\mathrm{g} / \mathrm{dL})$} & 39.00 & 38.94 & 28.71 & 27.34 \\
\hline & \pm & \pm & \pm & \pm \\
\hline & $3.31^{\mathrm{a}}$ & $3.28^{\mathrm{a}}$ & $1.84^{\mathrm{c}}$ & $1.64^{\mathrm{d}}$ \\
\hline \multirow[t]{3}{*}{$\operatorname{PLt}\left(\mathrm{x} 10^{3} / \mu \mathrm{l}\right)$} & 186.60 & 188.60 & 237.60 & 247.60 \\
\hline & \pm & \pm & \pm & \pm \\
\hline & $40.32^{\mathrm{a}}$ & $25.11^{\mathrm{a}}$ & $51.81^{\mathrm{c}}$ & $52.54^{\mathrm{cd}}$ \\
\hline
\end{tabular}

Values are expressed as mean \pm SD, $n=10$. Means in a row with no common superscripts $(\mathrm{a}, \mathrm{b}, \mathrm{c}, \mathrm{d})$ are significantly different $(\mathrm{p} \leq 0.05)$.

Table 5: WBCs changes in catfish before and after DMSA exposure:

\begin{tabular}{|c|c|c|c|c|}
\hline Parameter & $\begin{array}{l}\text { Standard group } \\
\text { (Zero time) }\end{array}$ & $\begin{array}{l}\text { Unexposed DMSA } \\
\text { group (60 days) }\end{array}$ & $\begin{array}{l}\text { Low dose } \\
\text { DMSA } \\
\text { group }(60 \\
\text { days })\end{array}$ & $\begin{array}{l}\text { High dose DMSA } \\
\text { group (60 days) }\end{array}$ \\
\hline WBCs $\left(\times 10^{3} / \mathrm{mm}^{3}\right)$ & $9470 \pm 4.4292^{\mathrm{a}}$ & $10660 \pm 1.5143^{b}$ & $7840 \pm 2.3362^{c}$ & $6640 \pm 2.9290^{c}$ \\
\hline Neutrophils $(\%)$ & $57.90 \pm 6.2^{\mathrm{a}}$ & $57.00 \pm 5.20^{\mathrm{a}}$ & $45.50 \pm 4.87^{\mathrm{c}}$ & $45.00 \pm 5.61^{c}$ \\
\hline Eosinophils (\%) & $3.10 \pm 0.5^{\mathrm{a}}$ & $3.80 \pm 0.55^{\mathrm{a}}$ & $1.30 \pm 0.45^{\mathrm{c}}$ & $1.40 \pm 0.71^{c}$ \\
\hline Lymphocytes (\%) & $30.00 \pm 6^{\mathrm{a}}$ & $30.00 \pm 5.00^{\mathrm{a}}$ & $46.40 \pm 5.23^{c}$ & $46.20 \pm 5.08^{c}$ \\
\hline Monocytes (\%) & $9.00 \pm 2.6^{\mathrm{a}}$ & $9.20 \pm 2.39^{\mathrm{a}}$ & $6.80 \pm 1.30^{c}$ & $6.80 \pm 1.30^{c}$ \\
\hline
\end{tabular}

Values are expressed as mean $\pm \mathrm{SD}, \mathrm{n}=10$. Means in a row with no common superscripts $(\mathrm{a}, \mathrm{b}, \mathrm{c}, \mathrm{d})$ are significantly different $(\mathrm{p} \leq 0.05)$.

\section{The effect of DMSA exposure on liver function}

A significant $(\mathrm{p} \leq 0.05)$ decrease in AST and ALT activities after DMSA exposure as compared to unexposed and standard groups (Table 6). Also, TSD test revealed that there was a significant difference in AST and ALT activities between low and high dose DMSA exposed groups.

Table 6: Changes in liver function of catfish before and after DMSA exposure:

\begin{tabular}{ccccc}
\hline Parameters & $\begin{array}{c}\text { Standard } \\
\text { group } \\
\text { (Zero time) }^{\text {a }}\end{array}$ & $\begin{array}{c}\text { Unexposed } \\
\text { DMSA group } \\
\text { (60 days) }\end{array}$ & $\begin{array}{c}\text { Low dose } \\
\text { MSA Group } \\
(\mathbf{6 0} \text { days) }\end{array}$ & $\begin{array}{c}\text { High dose } \\
\text { DMSA group } \\
\text { (60 days) }\end{array}$ \\
\hline AST (U/L) & $107.7 \pm 23.7^{\mathrm{a}}$ & $206.20 \pm 67.32^{\mathrm{b}}$ & $96.00 \pm 29.59^{\mathrm{c}}$ & $87.00 \pm 17.39^{\mathrm{cd}}$ \\
\hline ALT (U/L) & $113.4 \pm 35.00^{\mathrm{a}}$ & $217.40 \pm 29.20^{\mathrm{b}}$ & $69.40 \pm 12.58^{\mathrm{c}}$ & $57.00 \pm 8.78^{\mathrm{cd}}$ \\
\hline
\end{tabular}

Values are expressed as mean $\pm S D, n=10$. Means in a row with no common superscripts (a, b, c, $d)$ are significantly different $(\mathrm{p} \leq 0.05)$. 


\section{The effect of DMSA exposure on kidney function}

A significant $(P \leq 0.05)$ decrease in urea and creatinine values after DMSA exposure as compared to unexposed and standard groups (Table 7). TSD test revealed that there was significant $(P \leq 0.05)$ difference in urea and creatinine values between low and high dose DMSA exposed groups.

Table 7: Changes in kidney function of catfish before and after DMSA exposure:

\begin{tabular}{|c|c|c|c|c|}
\hline Parameters & $\begin{array}{l}\text { Standard group } \\
\text { (Zero time) }\end{array}$ & $\begin{array}{l}\text { Unexposed } \\
\text { DMSA group } \\
\text { (60 days) }\end{array}$ & $\begin{array}{l}\text { Low dose } \\
\text { DMSA group } \\
\text { (60 days) }\end{array}$ & $\begin{array}{l}\text { High dose } \\
\text { DMSA group } \\
\text { (60 days) }\end{array}$ \\
\hline $\begin{array}{c}\text { Urea } \\
\text { (mg/dl) } \\
\text { Creatinine }\end{array}$ & $32.60 \pm 5.68^{a}$ & $34.6 \pm 5.2^{b}$ & $24.00 \pm 7.97^{c}$ & $20.80 \pm 5.54^{c d}$ \\
\hline$(\mathrm{mg} / \mathrm{dl})$ & $0.63 \pm 0.15^{\mathrm{a}}$ & $0.87 \pm 0.5^{b}$ & $0.57 \pm 0.47^{c}$ & $0.43 \pm 0.17^{\mathrm{cd}}$ \\
\hline
\end{tabular}

Values are expressed as mean $\pm \mathrm{SD}, \mathrm{n}=10$. Means in a row with no common superscripts $(\mathrm{a}, \mathrm{b}, \mathrm{c}, \mathrm{d})$ are significantly different $(\mathrm{p} \leq 0.05)$.

\section{Oxidative marker and antioxidant enzymes}

A marked significant $(\mathrm{p} \leq 0.05)$ increase in catalase (CAT) glutathione peroxidase (GPX) and superoxide dismutase (SOD) was observed after exposure to DMSA than that of unexposed and standard groups (Table 8). TSD test revealed that there was no significant difference in CAT, GPX and SOD activities between low and high dose DMSA exposed groups.

Table 8: Changes in serum antioxidant enzyme activities of catfish before and after DMSA exposure:

\begin{tabular}{ccccc}
\hline Parameter & $\begin{array}{c}\text { Standard } \\
\text { group } \\
\text { (Zero time) }\end{array}$ & $\begin{array}{c}\text { Unexposed } \\
\text { DMSA group } \\
(\mathbf{6 0} \text { days) }\end{array}$ & $\begin{array}{c}\text { Low dose } \\
\text { DMSA group } \\
(\mathbf{6 0} \text { days) }\end{array}$ & $\begin{array}{c}\text { High dose } \\
\text { DMSA group } \\
\mathbf{( 6 0 ~ d a y s ) ~}^{\text {(6) }}\end{array}$ \\
\hline CAT $(\mathbf{U} / \mathbf{m l})$ & $32.60 \pm 9.6^{\mathrm{a}}$ & $29.80 \pm 6.54^{\mathrm{b}}$ & $51.20 \pm 9.42^{\mathrm{c}}$ & $52.80 \pm 6.57^{\mathrm{c}}$ \\
\hline GPx $(\mathbf{m U} / \mathbf{m l})$ & $35.00 \pm 16.9^{\mathrm{a}}$ & $28.60 \pm 7.37^{\mathrm{b}}$ & $60.40 \pm 18.26^{\mathrm{c}}$ & $61.00 \pm 9.35^{\mathrm{c}}$ \\
\hline SOD $(\mathbf{U} / \mathbf{m l})$ & $34.70 \pm 12.2^{\mathrm{a}}$ & $23.60 \pm 5.77^{\mathrm{b}}$ & $62.40 \pm 12.90^{\mathrm{c}}$ & $63.00 \pm 13.7^{\mathrm{c}}$ \\
\hline
\end{tabular}

Values are expressed as mean $\pm \mathrm{SD}, \mathrm{n}=10$. Means in a row with no common superscripts $(\mathrm{a}, \mathrm{b}, \mathrm{c}, \mathrm{d})$ are significantly different $(\mathrm{p} \leq 0.05)$.

\section{Histopathological findings \\ Light microscope}

The standard liver section of Clarias gariepinus (G1) revealed cytoplasmic vacuolation presenting a foamy appearance with Kupffer cells and fibrosis increment (Fig. A). The unexposed DMSA liver section (G2) displayed severe disorganization of the hepatic cords, damaged cell membrane, excessive necrosis of hepatocytes, associated with hemolysis, melanomacrophages aggregation and inflammatory leukocytic infiltration (Fig. B). The liver section of G3 exhibited less organized architecture with vacuolated area. Most of the hepatocyte with large spherical nuclei containing central prominent nucleolus and large Kupffer cell rest on the luminal surface of the sinusoids (Fig. C). The liver section of G4 showed clear signs of improvement included the arrangement of polygonal hepatocytes with centrally located nuclei separated by narrow blood sinusoids lined by endothelial cells (Fig. D).

The standard kidney section of G1 exhibited necrosis interstitial tissues, severe vacuolation of tubular epithelium with large intracytoplasmic vacuoles. Also, wide Bowman's space and fibrosis were noticed (Fig. A). The unexposed DMSA kidney section (G2) demonstrated atrophied glomeruli capillaries with wide Bowman's space, complete necrosis of fused renal tubules and hyperplasia of interstitial tissues with complete loss of cellular histological architecture (Fig. B). The kidney section of 
G3 showed partial improved state where, the tubular segment is lined with epithelial cells with central basal nuclei and presence of glomeruli separated by nearly normal interstitial tissues (Fig. C). The kidney section of G4 showed healthy renal tubules with high cuboidal cells and weak eosinophilic cytoplasm (Fig. D).

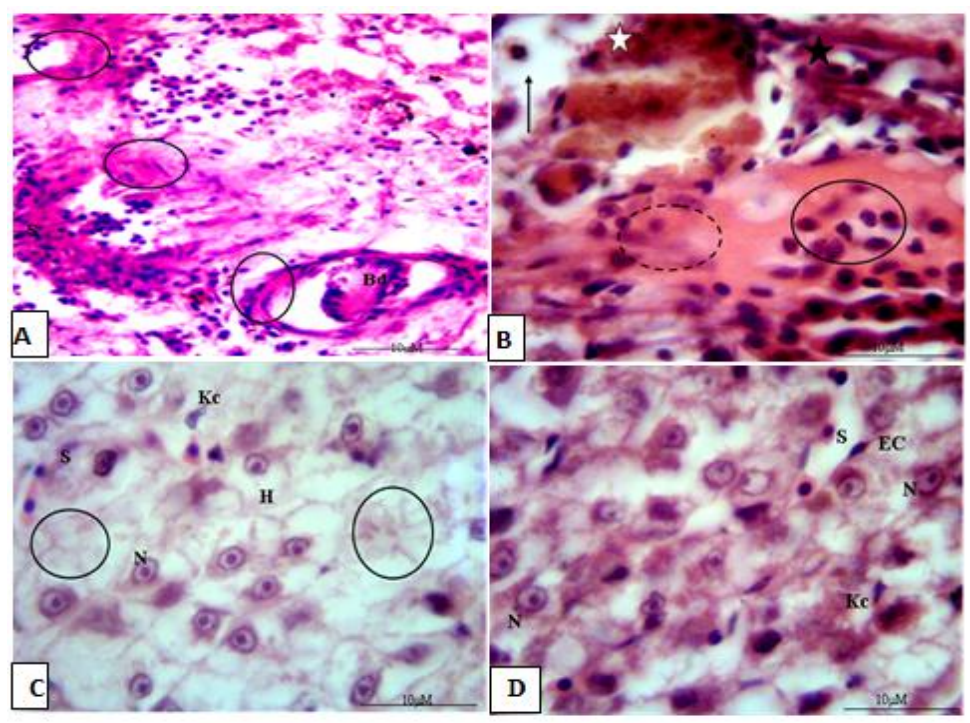

Light micrographs (100X H\&E stain): (A) G1 liver sections showing disappearance of normal architecture with fibrosis (circles) in the cytoplasm and around bile ductule (Bd) with foamy area and Kupffer cells. (B) G2 liver sections showing aggregation of leukocytes (circle), melanomacrophage (white asterisk) and hemolysis (dashed circle). (C) G3 liver sections showing: vacuolated area (circle), pale nucleus (N) with large nucleolus and hypertrophied Kupffer cell (Kc). (D) G4 liver sections showing improved polyhedral hepatocytes with central nucleus (N), sinusoids lined with endothelial cell (EC) and contained Kupffer cell (Kc).

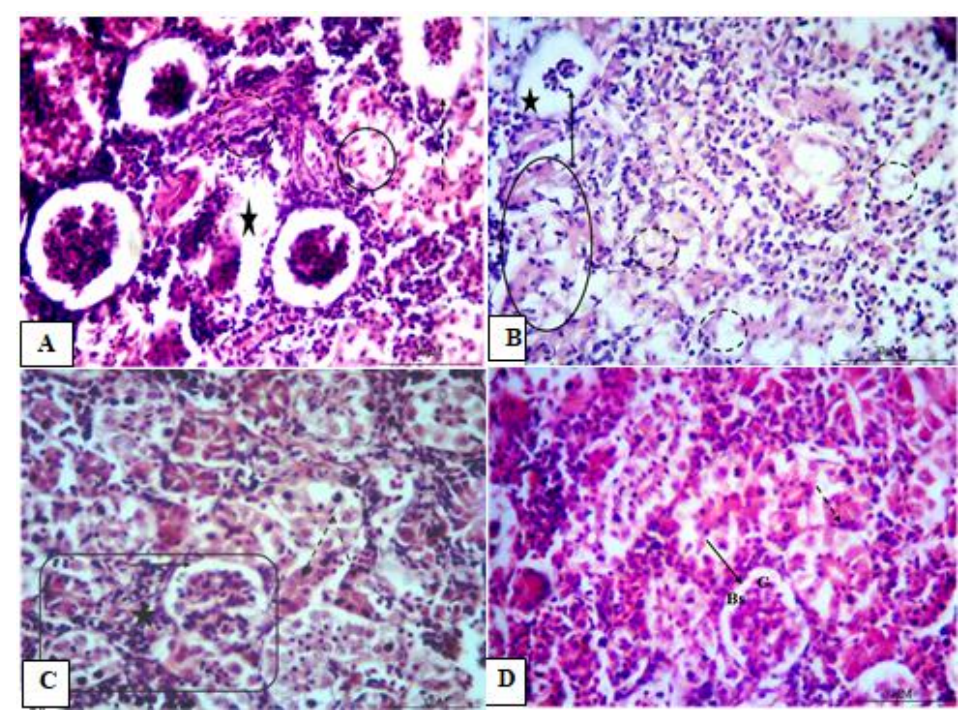

Light micrographs (40X. H\&E stain): (A) G1 kidney sections showing atrophied glomerulus with lytic Bowman's capsule (dashed arrow), vacuolated renal tubules (circle), fibrosis (dashed circle) and necrosis (asterisk). (B) G2 kidney sections showing atrophy with destruction of glomerular capillaries (arrow), wide Bowman's space (asterisk), tubules fusion (circle), and vacuolated tubule (dashed-circle). (C) G3 kidney sections showing less improved renal tubules (arrows) with basal nuclei in interstitial tissues (asterisk) and Bowman's capsule (square). (D) G4 kidney sections showing improved glomerulus (G) surrounded by the Bowman's capsule (arrow), Bowman's spaces (Bs) round renal tubules (dashed arrow).

\section{Electron microscope}

The standard liver hepatocytes (G1) showed disorganized cytoplasm with absence of most organelles and occupied by lipid vesicles (Fig. A). Also, abnormal 
nuclei with prominent nucleolus, folded nuclear envelope, proliferation of bizarreshaped mitochondria, loss of structural integrity of $\mathrm{rER}$, increase in the number of primary and secondary lysosomes with variable sizes (Fig. B). The unexposed DMSA liver section (G2) showed nuclei with severe irregularities in shape and irregular masses of heterochromatin covered the whole nucleus.
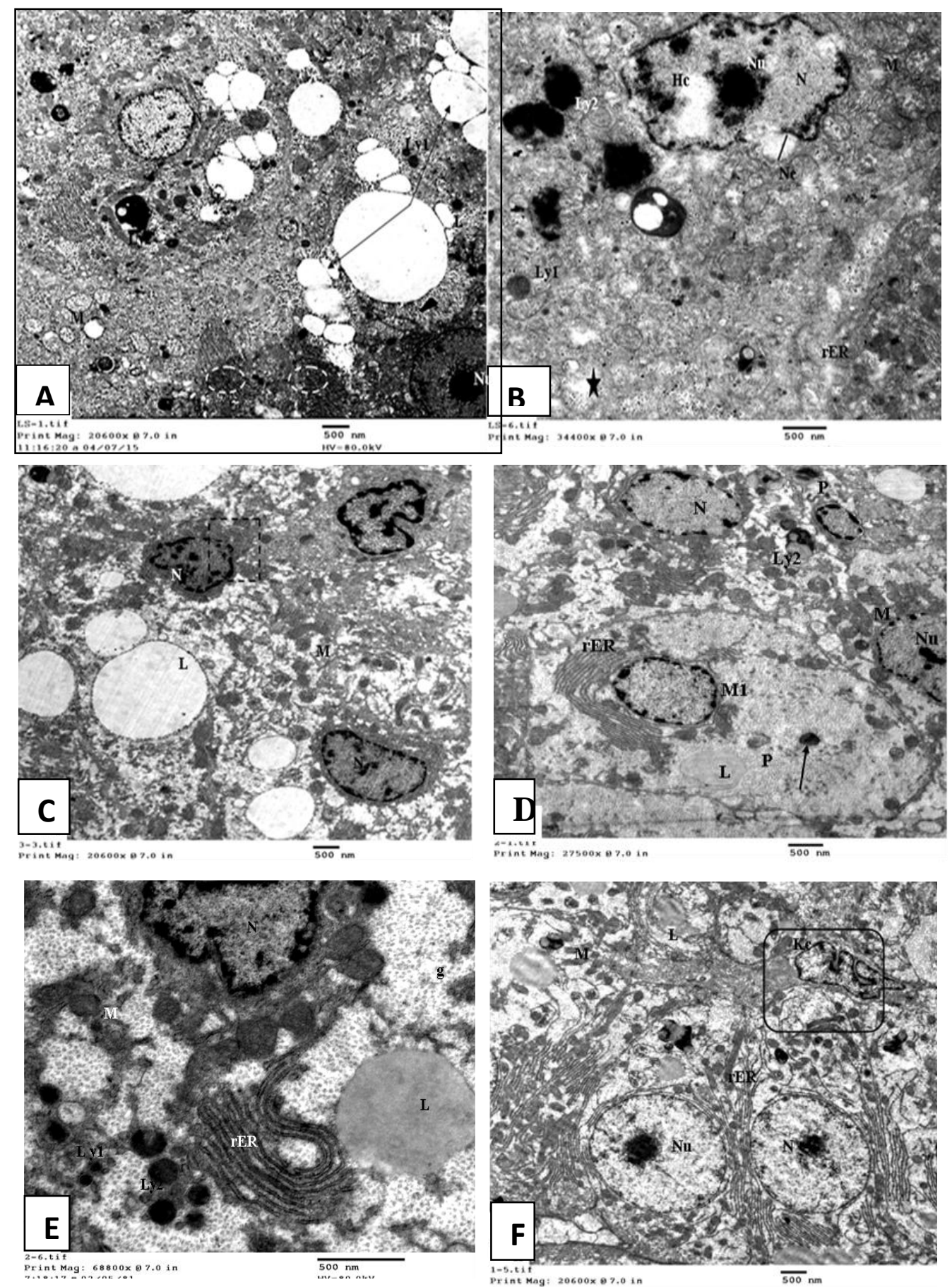

Electron micrographs: (A, B) G1 liver section showing lipid augmentation (arrows), mitochondria (M), lysosome $(\mathrm{Ly})$, irregular nucleus $(\mathrm{N})$, disrupted nucleolus $(\mathrm{Nu})$, destruction of nuclear envelope $(\mathrm{Ne})$, depletion of rough endoplasmic reticulum (rER), degenerated mitochondria (star), primary (Ly1) and secondary (Ly2) lysosomes. (C) G2 liver section showing irregular nuclei (N-square), proliferative mitochondria (M), fat droplets (L) in affected cytoplasm. (D, E) G3 liver sections showing round nuclei $(\mathrm{N})$ with peripheral masses of heterochromatin, rough endoplasmic reticulum with parallel cristae (rER), proliferation of primary lysosome (arrow), secondary lysosome (Ly2) and peroxisome (P), lipid droplets (L), aggregation of small mitochondria (M) or depletion (M1), glycogen (g). (F) G4 liver sections showing improved binucleated $(\mathrm{N})$ hepatocyte with prominent nucleolus $(\mathrm{Nu})$, 
mitochondria (M), few lipid droplet (L), organized rough endoplasmic reticulum (rER), and Kupffer cells (Kcsquare).

There was an increase in the lipid droplets and severe aggregation of small mitochondria Fig. C. Liver section G3 showed partial improvement in nuclei with random distribution of heterochromatin, rough endoplasmic reticulum stacks with non-fenestrated cisternae arranged in parallel array with round and megamitochondria (Fig. D). Proliferation of lysosomal elements including primary, secondary with few lipid droplets and large deposits of glycogen (Fig. E). The liver section G4 represented high improvement where, the hexagonal shape of typical hepatocytes, central round nucleus with distinct single nucleolus with high electron density and heterochromatin dispersed along the nucleoplasm. The rough endoplasmic reticulum was evident and arranged in parallel stacks of cisternae possessing high densities of ribosome adjacent to the nucleus Fig. F.

\section{DISCUSSION}

To accelerate the restoration of Lake Mariout to better conditions for saving them as grounds for fisheries, the quality of the sewage and industrial wastes dumping directly into them or indirectly via agricultural drains must be much improved by suitable means, at least by using DMSA for limiting the amounts of heavy metals demanding industrial wastes, especially lead and mercury . It was established that the polluted water weakens the fish host defenses against parasites, allowing increased opportunities for epizootic diseases to affect fish populations (Zeitoun and Mehana, 2014). From the achieved results, it was confirmed that water quality is an integral part of any aquaculture system and plays a major role in fish health. So, DMSA groups showed improve in water quality and increase the fish host defenses against infections and parasites.

In the current study, the lead $(\mathrm{Pb})$ accumulation among the different organs was arranged as follows: kidney $>$ gills $>$ blood $>$ liver $>$ muscle. The mercury $(\mathrm{Hg})$ accumulation pattern was liver $>$ kidney $>$ muscle $>$ gills $>$ blood as observed in this work.

The presence of these elements in both the gills and other tissues of fish in that study area agree with study of El-Shehawi et al. (2014) who stated that Lake Mariout is highly contaminated with heavy metals. Metals transport through the blood, thus, they are brought into contact with different organs and tissues of fish and consequently accumulated (Kaoud and El-Dahshan, 2010). The lead accumulation in the tissues of $C$. gariepinus was dependent on the exposure period and lead concentration (Al-Balawi et al., 2013). Kusemiju et al. (2012) found that the $C$. gariepinus gills contained the highest concentration of all the detected heavy metals, while the muscle tissue was the lowest. The excessive intake of metals may lead to high accumulation in the gills causing the precipitation of mucous on the gill surface membrane (Siraj et al., 2014) and structural damage (Abumourad et al., 2013).

Pugazhvendan et al. (2012) suggested that the liver is one of the important organs to accumulate $\mathrm{Pb}$ and disturb its regular function leads to death of fish. The high accumulation of these metals in the liver could be related to the fact that the liver played an important role in the accumulation and detoxification (Al-Balawi et al., 2013). Meanwhile, the kidney is the gateway for heavy metal detoxification in the body (Vinodhini and Narayanan, 2008). The enhancement of these metals may be due to presence of industrial, sewage and agricultural discharge (Kaoud and El-Dahshan, 2010). 
The determination of the transfer factor (TF) and the positive correlations $(\mathrm{P} \leq 0.05)$ between concentrations of metals in fish muscle and water indicated the direct accumulation of metals from the water to the fish. The transfer factor provides a straightforward, constructive method for assessing heavy metal accumulation for the purposes of health risk assessment of humans consuming the fish. In the present work, transfer factor for organs of DMSA groups was lower than that of unexposed, this important to save human health who consuming the fish from this Lake as reported by Canpolat et al. (2014).

In this study, DMSA exposure showed significant decrease in lead and mercury concentrations in kidney, liver, gill, muscle and blood. Volans et al. (2010) recorded a decrease in blood lead or mercury concentrations in the poisoned child using DMSA over the short- and long-term. The positive effect of DMSA may be attributed to its properties as a chelating agent (Flora et al., 2008). Lead binds to adjoining sulfur and oxygen atoms whereas mercury binds to sulfur atoms in succimer. DMSA has a wide therapeutic index and has advantages over dimercaprol and $\mathrm{CaNa}_{2}$ EDTA (Lowry, 2010). DMSA has been recommended for the treatment of lead and mercury in human (Masters et al., 2008). DMSA preferentially binds to lead, but can also increase the excretion of several other toxic metals, including mercury, to a lesser extent (Adams, 2009). DMSA may bond with lead or mercuric ions through a mechanism of thiol competition and conjugates mercury or lead (Bridges et al., 2009).

Anemia in lead poisoning results from impairment of hemoglobin production and changes in the RBC membrane. Lead's interference in heme biosynthesis is characterized by several unique enzyme blockades causing increased urinary deltaaminolevulinic acid (ALA), urinary coproporphyrin and erythrocyte zinc protoporphyrin (Lowry, 2010). Also, lead and mercury showed a high affinity for erythrocytes (Alves et al., 2006). Furthermore, the impairment in iron synthesis and absorption, causing microcytic hypochromic anemia (Kumar and Nandan, 2014).

There is also good evidence linking mercury with anemia, including hemolytic anemia and aplastic anemia as mercury is thought to compete with iron for binding to hemoglobin which can result in the impaired hemoglobin formation (Pyszel et al., 2005). The present finding came accordance with the results of Adeyemo (2007) and Mahmoud et al. (2013) who observed a decrease in RBC, Hb, and Hct values in Clarias gariepinus exposed to lead.

In this study, DMSA exposure completely improved the hematological parameters (RBC, Hb, Hct, MCV, MCH and MCHC). The present findings were in agreement with Gurer et al. (1998) who reported that treatment with a thiol antioxidant chelating agent (Succimer) has a reverse effect on the lead induced oxidative stress against accumulation and antioxidation of aminolevulinic acid (ALAD). Adams et al. (2009) recorded greatly improved abnormal platelet counts, suggesting a significant decrease in inflammation after oral DMSA therapy for children with autism spectrum disorders ages 3-8 years.

In the current work, the pronounced alterations in white blood cells were leucocytosis and lymphocytopenia in the unexposed DMSA group. This increase in WBCs may be attributed to immune response in lead exposed fish (Altindag, 2005). In addition, it has been known for many years that mercury impairs immune system function most likely via its deleterious effects on the polymorphonuclear leukocytes (PMNs). Mercury through suppression of adrenocorticosteroids production prevents normal stimulation of PMNs production and also affects the PMN function by inhibiting their ability to destroy foreign substances (Wada et al., 2009). These results 
came accordance with Olugh and Omerebele (2010) who recorded that there was a significant leucocytosis in the fish Clarias gariepinus exposed to lead poisoning. Zaki et al. (2014) reported that long term exposure of Clarias lazera to $\mathrm{Pb}$ and $\mathrm{Hg}$ caused a gradual increase in WBCs count. In this study, DMSA exposure completely improved the enhancement in WBC count. Significant increase in lymphocyte in exposed DMSA groups comparing with unexposed and standard groups.

Monitoring of liver enzyme leakage into the blood has proved to be a useful tool in liver toxicological studies (Abedi et al., 2013; Chavan and Muley, 2014). The increased activity of these enzymes in blood is correlated either with leakage of enzymes from the damaged hepatic cells into the blood stream or increased synthesis of these enzymes as a result of heavy metal toxicities (Osman et al., 2010). The activity of AST and ALT enzymes in blood may also be used as a stress indicator as mentioned by Awad Elkareem et al. (2014). Okonkw and Ejike (2012) and Olojo et al. (2012) stated that elevations in ALT and AST concentrations in serum of the catfish may be attributed to disruption of hepatic cells as a result of necrosis or altered membrane permeability after exposure to lead. The present findings were in agreement with Çoğun and Şahin (2013) who reported that $\mathrm{Pb}$ exposure increased the activities of ALT and AST in serum of Clarias gariepinus.

DMSA treatment showed a protective effect against hepatotoxicity as indicated by a significant decrease in AST and ALT activities. Adams et al. (2009) recorded that DMSA had no significant effects on liver transaminases (AST and ALT), perhaps because they treated for only 3 days at a time therapy for children with autism spectrum disorders ages 3-8 years. The present data from the liver function tests are corroborated by the histological changes observed in the liver sections of the test fish, relative to the control fish.

The level of $\mathrm{Pb}$ and its accumulation over time may cause serious damage to the renal system, over time, by continuous consumption of the fish and the water (ATSDR, 2007). The increase in creatinine level might be induced by glomerular insufficiency, increased muscle tissue catabolism or the impairment of carbohydrates metabolism (Hadi et al., 2009). Urea and creatinine are nitrogenous end products of protein metabolism, taken together the BUN and creatinine levels provide a very accurate estimation of how well the kidneys are working (Ajeniyi and Solomon, 2014).

Abdel El -Moneium et al. (2008) showed an insignificant difference in blood urea and significant increase in creatinine after exposure Clarias lazera to different doses of industrial effluent. An increase in the urea and creatinine in Clarias gariepinus after exposure to mercury and $\mathrm{Pb}$ was observed (Mahmoud et al., 2013). Zaki et al. (2014) reported that long term exposure of Clarias lazera to mercuric chloride and/or to $\mathrm{Pb}, \mathrm{Hg}, \mathrm{Ca}$ and/or lead acetate caused gradual elevation of serum urea and creatinine.

The present study revealed that DMSA had a protective effect against renal dysfunction as indicated by a decrease in the urea and creatinine levels. Chelating agents are capable of binding to toxic metal ions to form complex structures which are easily excreted from the body. Hydrophilic chelators like meso-2,3dimercaptosuccinic acid effectively promote renal metal excretion (Flora et al., 2011). These results in the same line with Adams et al. (2009) who recorded high urinary excretion of toxic metals ( $\mathrm{Pb}$ and mercury) suggesting an improvement in kidney functions after oral dimercaptosuccinic acid (DMSA) therapy for children with autism spectrum disorders ages 3-8 years. Bradberry and Vale (2009) stated that 
DMSA at a dose $30 \mathrm{mg} / \mathrm{kg} /$ day was more effective than 10 or $20 \mathrm{mg} / \mathrm{kg} / \mathrm{day}$ in enhancing urinary lead excretion.

Fish inhabiting the highly polluted sites developed an increased state of oxidative stress characterized by increased levels of lipid peroxidation (Rajeshkumar et al., 2013). Lead alters the activity of antioxidant enzymes like SOD, CAT and GPx (Flora et al., 2008). Lead and mercury have electron-sharing affinities causing the formation of covalent attachments mainly between heavy metal and sulfhydryl groups of several enzymes in antioxidant defense system, causing inactivation of these enzymes. Overall, these inhibitory effects of lead on various enzymes would probably result in impaired antioxidant defenses by cells and render cells more vulnerable to oxidative attacks.

Saliu and Bawa-Allah (2012) showed reduced levels of SOD and CAT occurred in Clarias gariepinus exposed to lead. They studied the effects of mercury on the activities of antioxidant defenses in intestinal macrophages of fresh water teleost Channa punctatus suggesting the use of these antioxidants as potential biomarkers of toxicity associated with exposure of freshwater fish to contaminants. Mercury has a high affinity for sulfydryl (-SH) groups, inactivating sulfur-containing antioxidants with subsequent decreased oxidant defense and increased oxidative stress (Begam and Sengupta, 2014).

DMSA exposure has an antioxidant effect as documented by elevations in the antioxidant enzymes activities. Flora et al. (2008) recorded a reduction in oxidative stress in the blood of male Wistar rats were exposed to $0.1 \%$ lead acetate in drinking water for 3 months after DMSA therapy. Sompamit et al. (2013) recorded a reduction in oxidative stress in blood mice after DMSA at a dose of $25 \mathrm{mg} / \mathrm{kg}$ or 50 $\mathrm{mg} / \mathrm{kg}$ for 5 consecutive days after 8 weeks of Cd exposure.

Most DMSA in plasma is protein-bound through a disulfide bond with cysteine; only a very small amount is present as free drug, which is filtered at the glomerulus then extensively reabsorbed into proximal tubule cells. DMSA therefore accumulates in the kidney where it is extensively metabolized to mixed disulfides of cysteine which are active chelating agents. A chelating agent has at least two negatively charged groups that allow it to form complexes with metal ions with multiple positive charges, such as lead and mercury. The chelate that is thus formed is nontoxic and can be excreted in the urine (Bradberry and Vale, 2009).

In the present study, the histopathological alterations in the liver of the studied fish collected from the Lake Mariout (Standard group) and unexposed DMSA group might be due to the oxygen deficiency as a result of gill degeneration which is the most common cause of cellular degeneration of the liver. Also, hepatocytes wall degeneration, high number of Küffer cells, infiltration of leukocytes indicate increased inflammation and fibrosis in the hepatic tissues as reported by Koca (2008). The manifestation of cytopathologic changes suggests a severe hepatic dysfunction and the impairment of the physiometabolic process in the liver (Dezfuli et al., 2006). AlBalawi et al. (2013) showed that necrosis of hepatocytes was apparent in the fishes (Clarias gariepinus) exposed to lead.

In this study, ultra-examination of standard liver hepatocytes showed the necrotic appearance with lytic nuclei or pyknotic nucleus with multivesicular appearance and an extremely folded nuclear envelope. In addition, blood sinusoid lined with small flat endothelial cell has irregular nucleus, hypertrophied Kupffer cell and strongly developed cytoplasmic myelinated bodies. These can be explained as, disturbance of living processes at the molecular and subcellular levels of biological organization by xenobiotics which can lead to cell injury, resulting in degenerative 
and neoplastic diseases in target organs (Pacheco \& Santos, 2002). The increased number of lysosomes, a result of the attempt to digest heavy metals or toxic substances, is considered a general manifestation of injury. These results were consistent with the results of Abdel-Moneim and Abdel-Mohsen (2010) and Sayed et al. (2012).

In the present study, the standard fish kidneys and unexposed DMSA group showed histopathological changes. The changes in the size, structure of the epithelial cells and the narrow lumen of the renal tubule inhibits kidney functioning (Gupta and Srivastava, 2006) and these were well documented in this study by biochemical and physiological results. Mohamed (2009) observed necrosis of tubular epithelium, hypertrophied epithelial cells of renal tubules, narrowing of the tubular lumen, expansion of space inside the Bowman's capsules and contraction of the glomerulus in C. carpio exposed to sewage. Abd-Elghaffar et al. (2015) recorded that the kidneys treated with lead acetate showed severe tubular necrosis, periglomerular lymphoid cell reaction, dilatation of renal tubule, hyaline tubular cast associated with hemorrhage.

It has been indicated that chelating agent, like DMSA, reduces the toxic effect of heavy metals on the histological alterations of soft tissues (Raafat et al., 2011). Abd-Elghaffar et al. (2015) proved that rats treated with lead acetate combined with DMSA (50 mg/kg /week) only have improved effect.

\section{CONCLUSION}

The protective effect of DMSA may be attributed to its activity as a chelating agent which is act as a scavenger molecule with at least two negatively charged groups that allow it to form complexes with metal ions such as lead and mercury.

\section{Conflict of interest:}

The authors declare no conflict of interest.

\section{REFERENCES}

Abd-Elghaffar, S.K.H.; El-Sayed, M.F.; Adly, M.A. and Abdel-Samei, W.M. (2015). The protective effects of DMSA and some vitamins against toxicity induced by lead in male Albino rats. J. Pharm. Appl. Chem., 1(1): 1-8.

Abdel-Moneim, A.M. and Abdel-Mohsen, H.A. (2010). Ultrastructure changes in hepatocytes of catfish (Clarias gariepinus) from Lake Maryout. Egypt. J. Enviro. Biol., 31(5): 715-720.

Abdel-Moneium, A.M.; Abou Shabana, N.M.; Khadre, S.E.M. and Abdel-Kader, H.H. (2008). Physiological and histological effects on (Clarias lazera) exposed to dyestuff and chemical wastewater. Int. J. Zool. Res., 4(4): 189-202.

Abedi, Z.; Hasantabar, F.; Khalesi, K. and Babaei, S. (2013). Effect of sublethal concentrations of cadmium, lead and chromium on some enzymatic activities of common carp, Cyprinus carpio. World J. Zoo., 8(1): 98-105.

Abei, H. (1984). Determination of Malondialdehyde. Method Enzymol., 105: 121126.

Abumourad IMK, Mohammad MN and Abbas WAT. 2013. Heavy Metal Pollution and Metallothionein Expression: A Survey on Egyptian Tilapia Farms. J. Appl.Sci. Res., 9 (1): 612-619.

Adams, J.B.; Baral, M. and Geis, E. (2009). Safety and efficacy of oral DMSA therapy for children with autism spectrum disorders: Part A-Medical results. BMC Clini. Pharm. 9:1186-1472. 
Adeyemo, O.K. (2007). Haematological profile of (Clarias gariepinus) exposed to lead. Turkish J. Fish. Aqua. Sci., 7: 163-169.

Agency for Toxic Substances and Disease Registry (ATSDR). (2007). Toxicological profile for lead. Public Health Service, U.S. Department of Health and Human Services, Atlanta, GA: U.S. Department of Public Health and Human Services, Public Health Service.

Ajeniyi, S.A. and Solomon, R.J. (2014). Urea and creatinine of (Clarias gariepinus) in three different commercial ponds. Nature and Science, 12(10).

Al-Balawi, H.F.A.; Al-Akel, A.S.; Al-Misned, F.; Suliman, E.M.; Al-Ghanim, KA.; Mahboob, S. and Ahmad Z. (2013). Effects of sub-lethal exposure of lead acetate on histopathology of gills, liver, kidney and muscle and its accumulation in these organs of (Clarias gariepinus). Brazil. Arch. Biol. Tech. 56(2): 293-302.

Altindag, A. and Yigit, S. (2005). Assesment of heavy metal concentration in the food web of Lake Beysehir, Turkey. Chemosphere. 60: 552-556.

Alves, L.C. and Wood, C.M. (2006). The chronic effects of dietary lead in freshwater juvenile rainbow trout (Oncorhynchus mykiss) fed elevated calcium diets. Aquat. Toxicol. 78: 217.

Amr, H.M.; El-Tawila, M.M. and Ramadan, M.H.M. (2005). Assessment of pollution levels in fish and water of main basin, Lake Mariout. The Journal of the Egyptian Public Health Association (JEPHAss.), (80): 1, 2.

Awad Elkareem, M.M.A.; Karrar, A.M.H. and Ali, A.K.S. (2014). Relationship of biometric size-weight, nutritive value, and metal concentrations in (Clarias lazera) (Cuvier and Valenciennes) reared in treated waste water. Jordan Journal of Biological Sciences. , 7(3): $217-225$.

Bancroft, J.D. and Gamble, M. (2002). Theory and practice of histological techniques. Neuro. J \& Exp. Neuro., 67(6):633.

Begam, M. and Sengupta, M. (2014). Effects of mercury on the activities of antioxidant defenses in intestinal macrophages of fresh water teleost (Channa punctatus). Int. J. of Fish. and Aqu. Stud., 2(1): 172-179.

Bradberry, S. and Vale, A. (2009). Dimercaptosuccinic acid (succimer; DMSA) in inorganic lead poisoning. Clin Toxicol (Phila)., 47(7):617-31.

Bridges, C.C.; Joshee, L. and Zalups, R.K. (2009). Effect of DMPS and DMSA on the placental and fetal disposition of methylmercury. Placenta, 30:800-805.

Canpolat, Ö.; Mücahit, E.; Mehmet, Z.Ç. and Mustafa, D. (2014). Transfer factors and bioaccumulation of some heavy metals in muscle of a freshwater fish species: a human health concern. Fresenius Environmental Bulletin, 23(2):418425.

Chavan, V.R. and Muley, D.V. (2014). Effect of heavy metals on liver and gill of fish (Cirrhinus mrigala). Int. J. Curr. Microbiol. App. Sci., 3(5): 277-288.

Cogun, H.Y. and Şahin, M. (2012). The effect of zeolite on reduction of lead toxicity in Nile Tilapia (Oreochromis niloticus Linnaeus, 1758). Kafkas Univ Vet Fak Derg. 18 (1): 135-140.

Dacie, J.V. and Lewis, S.M. (1975). Practical haematology. The English Language Book Society and Churchill Livingston. 32-34.

Damian, E.C.; Afulenu, N.L.; Obinna, O.M. and Ndidi, O.C. (2014). Bioaccumulation of heavy metals in fish sourced from environmentally stressed axis of River Niger: Threat to ecosystem and public health. In. J. Enviro. Prot. Pol., 2(4): 126-131. 
Dezfuli, B.S.; Simoni, E.; Giari, L. and Manera, M. (2006). Effects of experimental terbuthylazine exposure on the cells of (Dicentrarchus labrax). Chemosphere, 64: 1684-1694.

Diaz-Ravina, M.; Baath, E. and Frostegard, A. (1994). Multiple heavy metal tolerance of soil bacterialcommunities and its measurement by a thymidine incorporation technique. Appl. Environ. Microbio., 60: 2238-2247.

Ebrahimi, M. and Taherianfard, M. (2011). The effects of heavy metals exposure on reproductive systems of cyprinid fish from Kor River. Iranian J. Fish. Sci., 10 (1): 13.

El-Bestawy, A.H.; Attia, A.M. and Zahran, H. (2014). Biodegradation of persistent chlorinated hydrocarbons using selectedfreshwater bacteria. J. Bio. \& Biod. J Bioremed Biodeg., 5:4.

El-Shehawi, A.M.; Ali, F.K. and Seehy, M.A. (2014). Estimation of water pollution by genetic biomarkers in tilapia and catfish species shows species-site interaction. African Journal of Biotechnology, 6 (7): 840-846.

El-Sheikh, M.A.; Saleh, H.I.; El-Quosy, D.E. and Mahmoud, A.A. (2010). Improving water quality inpolluted drains with free water surface constructed Wetlands. Ecol. Engineer., 36: 1478-1484.

Emam, A.N.M. and Badia, A. (2014). Seasonal histological changes in gonads of the catfish (Clarias lazera). Fish. Aquac J., 5: 087.

Falayi, B.A. and Amatosero, R.B. (2014). The effects of lead (Pb) on (Clarias gariepinus) (B.) Juveniles in captivity research. J. Agricul. Environ. Manag., 3(8): 353-360.

Flora, S.J.S.; Mittal, M. and Mehta, A. (2008). Heavy metal induced oxidative stress \& its possible reversal by chelation therapy. Indian. J. Med. Res., 128: 501-523.

Flora, S.J.; Pachauri, V. and Saxena, G. (2011). Arsenic, cadmium and lead. In: Reproductive and Developmental Toxicology. Acad. Press., 415-438.

Gupta, A.K. and Kumar, A. (2006). Tilaknagar Udaipur. Histopathological lesions in the selected tissues of (Cirrhinus mrigala) (Ham.) fingerlings exposed to sub lethal concentration of mercury. J. Environ. Biol., 27(2):235-239.

Gurer, H.; Ozgunes, H.; Neal, R.; Spitz, D.R. and Ercal, N. (1998). Antioxidant effects of $\mathrm{N}$-acetyl cysteine and succimer in red blood cells from lead exposed rats. Toxicol., 128: 181-9.

Hadi, A.; Shokr, A. and Alwan, S.V. (2009). Effects of aluminum on the biochemical parameters of fresh waterfish (Tilapia zillii). J. Sci. Applica., 3: 33

Henry, R.J.; Cannon, D.C. and Winkelman, W. (1974). Clinical chemistry principles and techniques. $11^{\text {th }}$ ed., Harper and Row Publishers, New York. 1629.

Kanno, J.; Akagi, H. and Takabatake, E. (1985). A method for determination of methylmercury in environmental samples, particularly in sediment, Japanese. J. Toxicol. Enviro. Heal. (Eisei kagaku),. 31: 260-268.

Kaoud, H.A. and El-Dahshan, A.R. (2010). Bioaccumulation and histopathological alterations of the heavy metals in (Oreochromis niloticus) fish. Nat. Sci., 8(4).

Koca, S.; Koca, Y.B.; Yildiz, S. and Gürcü, B. (2008). Genotoxic and histopathological effects of water pollution on two fish species, (Barbus capito pectoralis and Chondrostoma nasus) in the Büyük Menderes River, Turkey. J. Biol. Trace Elem. Res., 122: 276-291.

Krishna, K.; Rama, M.K. and Murthy, N.N. (2013). Assessment of heavy metal contamination in soils around chromite mining areas, Nuggihalli, Karnataka, India. Environmental Earth Sciences, 70(2): 699. 
Kumar, G.B. and Nandan, B.S. (2014). Copper Toxicity: haematological and histopathological changes and prophylactic role of vitamin $\mathrm{C}$ in the fish, Anabastestudineus Bloch, 179. J. Zool. Stud., 1(3): 04-13.

Kusemiju, V.; Patience, A.; Aderinola, J. and Oluwatoyin. (2012). Accumulation of lead in the tissues of freshwater catfish (Clarias gariepinus) exposed to static nominal concentrations of lead nitrate. Agric. Biol. J. N. Am., 3(12): 510-515.

Lowry, J.A. (2010). Oral chelation therapy for patients with lead poisoning. Division of Clinical Pharmacology and Medical Toxicology, 4(1):173-.

Mahmoud, U.M.; Ebied, A.B. and Mohamed, S.M. (2013). Effect of lead on some haematological and biochemical characteristics of Clarias gariepinus dietary supplemented with lycopene and vitamin E. Egypt. Acad. J. Biolog. Sci., 5: (1): $67-89$.

Masters, S.B.; Trevor, A.J. and Katzung, B.G. (2008). Katzung \& Trevor's Pharmacology: Examination \& Board Review (8th Ed.). McG. H. Med. 481-3.

Mohamed, F.A.S. (2009). Histopathological studies on (Tilapia zillii and Solea vulgaris) from Lake Qarun, Egypt. W. J. Fish. Mar. Sci., 1 (1): 29-39.

Nishikimi, M.; Roa, N.A. and Yogi, K. (1972). Biochem. Bioph.Res.Common., 46: 849-854.

Okonkwo, F.O. and Ejike, C.E. (2011). Simulation of heavy metal contamination of fresh water bodies: toxic effects in thecatfish and its amelioration with cocontamination with glyphosate. J. Appl. Sci. Environ. Manage., 15(2): 341 345.

Olabanji, I.O. and Oluyemi, E.A. (2014). Preliminary assessment of heavy metal pollution of Opa Reservoir. Ile- Ife, Southwest Nigeria using Mormyrus Rumea (Tilapia zillii). Ife. J. Sci. 16: 1.

Olojo, E.A.A.; Abass, A.A.; Olurin, K.B. and Mbaka, G. (2012). The potential use of certain protein metabolism parameters as biomarkers of heavy metal (lead) stress in the African cat fish (Clarias gariepinus). Agri. J., 7: (5):316-322.

Oluah, N.S. and Omerebele, U.A.M. (2010). Changes in haematological parameters of (Clarias gariepinus) exposed to lead poisoning. J. Fish. Int., 5(4):72-76.

Osman, A.G.M.; Al-Awadhi, R.M.; Harabawy, A.S.A. and Mahmoud, U.M. (2010). Evaluation of the use of protein electrophoresis of the African catfish (Clarias gariepinus) for biomonitoring aquatic pollution. Environ. Res. J., 4(3): 235243.

Pacheco, M. and Santos, M.A. (2002). Biotransformation, genotoxic, and histopathological effects of environmental contaminants in European ell (Anguilla anguilla L.). Ecotoxicol. Environ. Saf., 53: 331-347.

Paglia, D.E. and Valentine, W.N. (1976). Studies on the quantitative and qualitative characterization of erythrocyte of glutathione peroxidase. J. Lab. Clin. Med., 7:158-169.

Palaniappan, R.M. and Vijayasundaram, V. (2009). The effect of arsenic exposure and the efficacy of DMSA on the proteins and lipids of the gill tissues of (Labeo rohita). Food. Chem. Toxicol., 47:1752-1759.

Pugazhvendan, S.R.; Mariappan, M.; Leon, P.S. and Balakrishnan, J.K. (2012). Bioaccumulation of lead in fresh water fish (Cyprinus Carpio). Int. J. C. Res., 4 (7):146-148.

Pyszel, A.; Wrobel, T.; Szuba, A. and Andrzejak, R. (2005). Effect of metals, benzene, pesticides and ethylene oxide on the haematopoietic system. Med Pr., 56(3):249-255. 
Raafat, M.; El-Barbary, A.; Touson, E. and Aziz, S. (2011). Dimercapto succinic acid (DMSA) and vitamin $\mathrm{C}$ chelating potency in lead intoxication, regarding oxidative stress and apoptotic proteins in rabbit. J. Gen. Engin. Biotech., 9:121131.

Rajeshkumar, S.; Jayaprakash, M. and Munuswamy, N. (2013). Effects of heavy metals on antioxidants and expression of HSP70 in different tissues of milk fish (Chanos chanos) of Kaattuppalli Island, Chennai, India. Ecot. Environ. Saf., 98 (1): 8-18.

Reitman, S. and Frankel, S.A. (1957). Colorimetric method for the determination of serum glutamic oxalacetic and glutamic pyruvic transaminases. Am. J. Clin. Pathol., 28: 56-63.

Reynolds, E.S. (1963). The use of lead citrate at high $\mathrm{pH}$ as an electron-opaque stain in electron microscopy. J. Cell Biol. 17: 208.

Saliu, J.K.; Saliu, K.A and Bawa-Allah. (2012). Toxicological effects of lead and zinc on the antioxidant enzyme activities of post juvenile Clarias gariepinus. Resources and Environment., 2(1): 21-26.

Sayed, A.H.; Mekkawy, I.A and Mahmoud, U.M. (2012). Histopathological alterations in some body organs of adult (Clarias gariepinus) exposed to 4Nonylphenol, Zoology, Dr. María- Dolores García (Ed.). Zoology. 8, 163-184.

Selander, S. and Cramer, K. (I968). Determination of lead in blood by atomic absorption spectrophotometry. Brit. J. Industr. Med. 25: 209.

Siraj, M.; Shaheen, M.; Sthanadar, A.A.; Khan, A.; Douglas, P.; Chivers, A.M. and Yousafzai. (2014). A comparative study of bioaccumulation of heavy metals in two fresh water species (Aorichthys seenghala and Ompok bimaculatous) at River Kabul, Khyber Pakhtunkhwa. Pakistan J. Bio. Env. Sci., 4(3):40-54.

Sompamit, K.; Kukongviriyapan, U.; Donpunha, W.; Nakmareong S. and Kukongviriyapan V. (2010). Reversal of cadmium-induced vascular dysfunction and oxidative stress by meso-2,3-dimercaptosuccinic acid in mice. Toxicol Lett., 198(1):77-82.

Tietz NW. (1995). Clinical Guide to Laboratory Tests. 3rd ed., Philadelphia, PA: WA Saunders Co. 622-626.

Vinodhini, R. and Narayanan, M. (2009). The impact of toxic heavy metals on the hematological parameters in common carp (Cyprinus carpio L.) Iran. J. Environ. Health. Sci. Eng. 6(1):23-2823.

Volans, G.N.; Karalliedde, L and Wiseman HM. (2010). Review of succimer for treatment of lead poisoning. Medical Toxicology Information Services, Mary Sheridan House, Guy's Hospital, London SE1 9RT.

Wada H.; Cristol DA.; McNabb, FM. and Hopkins WA. (2009). Suppressed adrenocortical responses and thyroid hormone levels in birds near a mercurycontaminated river. Environ Sci Technol., 43(15):6031-6038.

Zaki, M. and Osman, A. (2005). Histological changes in gill tissues of (Tilapia nilotica) exposed to lead chloride. Bull. Natio. Res. Cent. Cairo., 28(1):87-100.

Zeitoun, M.M. and Mehana, E.E. (2014). Impact of water pollution with heavy metals on fish health: Overview and Updates Global Veterinaria. 12(2): 219231. 